\title{
146. Immunological Studies of Pregnant Mare Serum Gonadotropin (PMSG). I
}

\author{
Preparation of Anti-PMSG and its Application to the \\ Pregnancy Test
}

\author{
By Shigenori Iкemoto, ${ }^{*}$ Harutaka Mukoyama, ${ }^{* *}$ Shozo \\ Suzuki, ${ }^{* *)}$ and Tanemoto Furuhata, M.J.A.***) \\ (Comm. October 12, 1964)
}

In 1930, Cole and Hart, ${ }^{1)}$ and Zondek ${ }^{2)}$ described a gonadotropic hormone obtained from the pregnant mare. Subsequent investigators ${ }^{3)}$ have proved that the hormone is produced by the chorionic tissue in the endometrial cup. In 1944-1963, Remington and Rowland, ${ }^{4)} \mathrm{Li}^{, 5)}$ and Wide ${ }^{6)}$ studied on the chemical, biological and immunological properties of this hormone. Aschheim and Zondek ${ }^{7)}$ published a biological assay technique for the detection of pregnancy and the quantitative determination of gonadotropin in pregnant mare serum. The present paper reports on the immunological reaction of the pregnant mare serum gonadotropin and the immunological pregnancy test by using this gonadotropin on pregnant mare serum.

1. Preparation of anti-PMSG serum. Commercial hormone (3,000 IU/mg., Tomoda Seiyaku Co., Ltd.) was incorporated into a complete Freund ${ }^{8)}$ adjuvant. The immunization was carried out according to Wide's method.9) The normal adult male albino rabbits were used for immunization, and the anti-PMSG serum was prepared by subcutaneous injection of 6,000 IU of PMSG suspended in $4 \mathrm{ml}$ of the Freund adjuvant at weekly intervals for eight weeks. The serum was heated for 30 minutes at $50^{\circ} \mathrm{C}$, and stored with $0.1 \%(\mathrm{w} / \mathrm{v})$ sodium azid at $5^{\circ} \mathrm{C}$.

Immunological test method. The precipitin test in liquid media was done according to Robert's method. ${ }^{10)}$ The studies using agar gel were performed according to a modification of Ouchterlony technique. ${ }^{10)}$ Hemagglutination test made according to the method described by Wide and Gemzell. ${ }^{11}$

Absorption test method. Non-specific anti PMSG was absorbed by precipitation. Nine volumes of non-specific anti-PMSG were mixed with one volume of non-pregnant mare serum. After absorption for

*) Laboratory of Legal Medicine, National Research Institute of Police Science, Tokyo.

**) Animal Breeding Laboratory, Tokyo Agricultural College.

***) Director, National Research Institute of Police Science, Tokyo. 

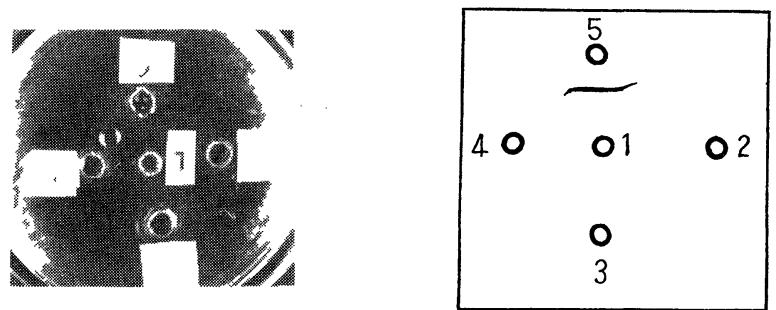

Reaction of antiserum with PMSG at a concentration of 1,000 IU per ml.

1) $1=$ Anti-PMSG (rabbit 1)

4) $4=$ Rabbit serum

2) $2=$ Bovine serum

5) $5=$ PMSG $1,000 \mathrm{IU}$ per ml

3) $3=$ Pig serum

2 hours at $37^{\circ} \mathrm{C}$, and for $24-48$ hours at $5^{\circ} \mathrm{C}$, the precipitates were removed by centrifugation at 5,000 r.p.m., for 15 minutes.

Results. The above figure shows the precipitation reaction on Ouchterlony plate using anti-PMSG serum obtained from a rabbit. A precipitation band appeared in dilution of 1,000 IU of PMSG per ml. Table I shows the precipitin reaction in micro-test tubes. The lowest concentration at which precipitation was visible, was 50 IU of PMSG per ml. At 2,000 IU of PMSG per $\mathrm{ml}$, the precipitation band was a broad one. Negative reaction was observed with control sera of rabbit, non-pregnant mare, gelding, and of pig. Table II shows the results of hemagglutination reaction. No agglutination was observed in the first tube of non-pregnant mare serum. The lowest concentration at which hemagglutination was visible, was 500 IU of PMSG per $\mathrm{ml}$. At 3,000 IU of PMSG per $\mathrm{ml}$ very strong clump agglutination occurred. In this study, PMSG preparation injected with Freund's adjuvant into adult male albino rabbits, induced the production of an anti-PMSG serum that had precipitin and agglutinin properties.

2. Pregnancy diagnosis studies. Collection of mare sera. Experiments were carried out on 34 pregnant mares, 20 non-pregnant

Table I. Reaction of PMSG with homologous antiserum in liquid media

\begin{tabular}{r|cccccccc|cccccc}
\hline $\begin{array}{r}\text { PMSG dilution } \\
(\mathrm{IU} / \mathrm{ml})\end{array}$ & 2,000 & 1,000 & 500 & 250 & 100 & 50 & 25 & $\mathrm{~Np}$ & $\mathrm{Ge}$ & $\mathrm{B}$ & $\mathrm{P}$ & $\mathrm{R}$ & $\mathrm{HCG}$ & $\mathrm{Bu}$ \\
Rabbit No. & 2 & 2 & 1 & 1 & 1 & 1 & 0 & 0 & 0 & 0 & 0 & 0 & 0 & 0 \\
\hline Rabbit 1 & 2 & 2 & 1 & 1 & 1 & 1 & 0 & 0 & 0 & 0 & 0 & 0 & 0 & 0 \\
Rabbit 2 & & & & & & & &
\end{tabular}

1) Observation interval 30 minutes

2) $2=$ Very strong positive reaction

7) $\mathrm{Ge}=$ Gelding serum

3) $1=$ Positive reaction

4) $0=$ Negative reaction

5) $\mathrm{Np}=$ Non-pregnant mare serum

8) $\mathrm{P}=\mathrm{Pig}$ serum

6) $B=$ Bovine serum

9) $\mathrm{R}=$ Rabbit serum

10) $\mathrm{HCG}=\mathrm{HCG} 100 \mathrm{IU}$ per $\mathrm{ml}$

11) $\mathrm{Bu}=$ Buffered saline 
Table II. Reaction of antiserum with PMSG at a coated of tannicacid treatment of formalinized sheep red cells

\begin{tabular}{c|c|c}
\hline Test tube & PMSG (IU/ml) & Hemagglutination \\
\hline 1 & Control rabbit serum & 0 \\
2 & 3,000 & 2 \\
3 & 2,000 & 2 \\
4 & 1,000 & 1 \\
5 & 800 & 1 \\
6 & 700 & 1 \\
7 & 500 & 1 \\
8 & 250 & 0 \\
9 & 100 & 0 \\
10 & 50 & 0 \\
11 & 25 & 0 \\
\hline
\end{tabular}

1) Observation interval 30 minutes

2) $2=$ Very strong positive reaction

3) $1=$ Positive reaction

4) $0=$ Negative reaction

mares, and 20 geldings. The diagnosis of pregnancy was made by clinical examination and biological pregnancy test. Blood samples were obtained by venipuncture under sterile condition. The serum was separated after 24 hours, and the samples were stored at $5^{\circ} \mathrm{C}$. The sera to be examined were diluted with equal volume of phosphate buffered saline at $\mathrm{pH}$ 7.0.

Biological assay. The biological assay was carried out according to the method described by Aschheim and Zondek.") Other precipitin tests were made according to the methods described previously.

Results. The results of the studies on sera of pregnant, nonpregnant mares and gelding are shown in Table III. The results of the pregnancy test by the precipitin test and biological assay are also summarized in Table III. Thirty-two cases of pregnant mare sera prepared from blood obtained between the 50-60th days after the last

Table III. Results of pregnancy test with anti-PMSG

\begin{tabular}{l|c|c|c}
\hline Mare sera & Pregnant mare sera & $\begin{array}{c}\text { Non-pregnant } \\
\text { mare sera }\end{array}$ & Gelding sera \\
\hline Technique & Positive 34 & 0 & 0 \\
Biological assay & Negative 0 & 20 & 20 \\
\hline \multirow{2}{*}{ Immunological } & Positive 32 & 0 & 0 \\
assay & Negative 2 & 20 & 20 \\
\hline
\end{tabular}

1) The results of studies on mare sera by precipitin technique.

2) The pregnant mare sera were collected on 50-60th day after the last copulation period. 
copulation period, gave positive reaction by precipitin test and biological assay, except for 2 cases that showed negative reaction in precipitin test. All sera of non-pregnant mares and geldings gave negative reaction by precipitin test and biological pregnancy test. In this study, by means of the precipitin test, it was possible to use the anti-PMSG serum for an immunological assay for pregnancy.

Summary. Preparation of pregnant mare serum gonadotropin (PMSG) was injected with the Freund's adjuvant into a rabbit, and induced the production of an anti-PMSG which showed precipitin and agglutinin properties. By means of this precipitin test, the antiPMSG serum may be used for immunological test for pregnancy. The antiserum also has antihormonal properties against the pregnant mare serum gonadotropin activity of the serum of pregnant mare.

Acknowledgement. The authors wish to thank Dr. T. Komai, M.J.A., and Dr. M. Watanabe, Dr. E. Fujiwara, and Dr. S. Ohkuma, of the National Research Institute of Police Science, and also to Dr. Yamamoto, of the Japan Light Breed Horse Association, for their interest and advice given to this work. The authors are indebted to Dr. M. Ugai, and Dr. K. Murakami, of the Tomoda Seiyaku Co., Ltd. Tokyo, for a generous supply of PMSG hormone.

\section{References}

1) Cole, H. H., and Hart, G. H.: Am. J. Physiol., 93, 57 (1930).

2) Zondek, B.: Die hormone des ovarium und des hypophysenvorderlappens. Springer, Berlin, p. 119 (1931).

3) Catchpol, H. R., and Lyons, D. R.: Am. J. Anat., 55, 167 (1934).

4) Remington, C., and Rowland, I. W.: Bioch. J., 38, 54 (1944).

5) Li, C. H.: Vitamines and Hormones, 7, 223 (1946).

6) Wide, M., and Wide, L.: Nature, 198, 1017 (1963).

7) Aschheim, S., and Zondek, B.: Klin. Wschr., 7, 1404 (1928).

8) Freund, J., and Dermott, K.: Proc. Soc. Exp. Biol., 49, 548 (1942).

9) Wide, L.: Acta. Ender., Sup., 70, 17 (1962).

10) Robert, G.: Experimental Immunology. Burgess Publishing, Min., pp. 43-54 (1962).

11) Wide, L., and Gemzell, C. A.: Acta. Ender. (Kbh.), p. 35261 (1960). 